\begin{tabular}{|c|c|c|c|c|}
\hline $\begin{array}{c}\text { Prosiding Penelitian \& } \\
\begin{array}{c}\text { Pengabdian Kepada } \\
\text { Masyarakat }\end{array}\end{array}$ & $\begin{array}{c}\text { e ISSN : 2581-1126 } \\
\text { p ISSN : 2442-448X }\end{array}$ & Vol 5, No: 2 & Hal: $176-187$ & Juli 2018 \\
\hline
\end{tabular}

\title{
PERAN PENDIDIKAN KARAKTER DI MASA REMAJA SEBAGAI PENCEGAHAN KENAKALAN REMAJA
}

\author{
Alima Fikri Shidiq ${ }^{1}$ \& Santoso Tri Raharjo ${ }^{2}$ \\ 1 Program Studi Kesejahteraan sosial, FISIP - Universitas Padjadjaran, Jl. Raya Bandung \\ Sumedang KM.21, Hegarmanah, Jatinangor, Kabupaten Sumedang, Jawa Barat 45363 \\ 2 Pusat Studi CSR, Kewirausahaan Sosial \& Pengembangan Masyarakat, FISIP - Universitas \\ Padjadjaran, Jl. Raya Bandung Sumedang KM.21, Hegarmanah, Jatinangor, Kabupaten \\ Sumedang, Jawa Barat 45363 \\ alima16001@unpad.ac.id; santoso.tri.raharjo@unpad.ac.id
}

\begin{abstract}
ABSTRAK
Remaja sebagai asset negara berperan sangat penting dalam proses pembangunan negara, dalam upaya peningkatan kualitas remaja dan pencegahan kenakalan remaja pemerintah membuat Perpres 87 No . 2017 tentang Penguatan Pendidikan Karakter, seiring dengan hal tersebut Pemerinta Kota Bandung membuat kebijakan Gerakan Maghrib Mengaji. Gerakan ini ditujukan bagi warga masyarakat kota Bandung agar dapat memanfaatkan waktu dengan mengisi selepas sholat Maghrib dengan kegiatan keagamaan atau pengkajian agama Islam. 'Gerakan Maghrib Mengaji' dapat menjadi wadah kegiatan bagi remaja, dengan mengisi kegiatan memperdalam dan memperluas pengetahuan dan pemahaman keagamaan. Sekaligus pula memperkuat karakter remaja dengan berlandaskan nilai dan norma religi yang kokoh. Penguatan karakter remaja yang berlandaskan pada nilai dan norma agama tersebut, diharpkan dapat mencegah timbulnya pemanfaatan waktu luang yang mengarah pada kegiatan-kegiatan tidak bermanfaat.

Salain itu, lingkungan juga berperan penting dalam proses perkembangan remaja, sebab lingkungan akan dijadikan media eksperimen oleh para remaja dalam mengimplementasikan pengetahuan yang mereka dapatkan, implementasi tersebut bisa berdampak baik bagi diri dan lingkungannya, namun bisa juga berdampak buruk bagi mereka. Sehingga perlu adanya pendidikan karakter yang mengarahkan pengetahuan remaja agar mereka tidak melakukan tindakan tindakan yang berakibat buruk, dan mengotori nilai norma yang terkandung di masyarakat seperti kenakalan remaja .
\end{abstract}

Kata kunci : Kenakalan remaja, pendidikan karakter, Maghrib mengaji, perkembangan remaja

\begin{abstract}
Adolescents as state assets play a very important role in the process of state development, in an effort to improve adolescent quality and prevention of juvenile delinquency of the government makes presidential decree 87 no. 2017 on strengthening character education, in line with the regulation of Bandung mayor make policy Maghrib Recitation Movement where Bandung city people can use their spare time to obtain knowledge about religion. Therefore Maghrib recitation reviewing this can be a place for teenagers to explore well without violating the prevailing values and norms, weighing adolescence is a time when the capacity to gain knowledge efficiently reaches its peak.
\end{abstract}




\begin{tabular}{|c|c|c|c|c|}
\hline $\begin{array}{c}\text { Prosiding Penelitian \& } \\
\begin{array}{c}\text { Pengabdian Kepada } \\
\text { Masyarakat }\end{array}\end{array}$ & $\begin{array}{c}\text { e ISSN : 2581-1126 } \\
\text { p ISSN : 2442-448X }\end{array}$ & Vol 5, No: 2 & Hal: $176-187$ & Juli 2018 \\
\hline
\end{tabular}

In addition, the environment also plays an important role in the process of adolescent development, because the environment will be used as an experimental medium by teenagers in implementing the knowledge they get, the implementation can have good impact for themselves and the environment, but it can also be bad for them. So that the need for character education that directs the knowledge of teenagers so that they do not take actions that result badly, and contaminate the value of norms contained in society such as juvenile delinquency.

Keywords: Juvenile delinquency, character education, Maghrib recitation, adolescent development

\section{Pendahuluan}

Pemerintah telah menyadari bahwa pembangunan fasilitas-fasilitas negara akan sangat percuma apabila unsur terpenting dalam suatu negara yaitu generasi muda (umumnya remaja) yaitu yang akan menggantikan mereka di masa yang akan datang tidak dikembangkan secara optimal. Sudah beberapa tahun ini pemerintah berupaya untuk meningkatkan kualitas sumber daya manusia khususnya kaum muda (remaja) terutama di bidang pendidikan, dari mulai program wajib sekolah, $\mathrm{PKH}$, Kartu Indonesia Pintar, dan program lainnya diluncurkan untuk mempermudah masyarakat Indonesia menempuh pendidikan formal.

Suprapto dan Ikhsan (dalam Kritiawan, 2015) menjelaskan bahwa ada begitu banyak beasiswa dan bantuan pendidikan untuk meningkatkan sumber daya manusia seperti dana BOS, BSM, DOS, dana CSR, dan lain-lain yang ditujukan dalam rangka perbaikan pengelolaan pendidikan yang demokratis dan akuntabel. Namun, sejumlah tradisi atau budaya yang tidak mendidik, mulai dari korupsi, kolusi, etos kerja rendah, intoleransi terhadap perbedaan, dan sifat kerakusan, sampai sifat ingin menang sendiri, kecenderungan menggunakan kekerasan dalam memecahkan masalah, pelecehan hukum, dan sifat oportunis, kesemuanya ini masih berlangsung, dan ini adalah hasil dari proses pendidikan kita .

Kondisi masyarakat sekarang yang sudah begitu mengagungkan ilmu pengetahuan mengakibatkan kaidah-kaidah moral dan tata susila yang dipegang teguh oleh orang-orang dahulu menjadi tertinggal di belakang. Dalam masyarakat yang telah terlalu jauh dari agama, kemerosotan moral orang dewasa sudah lumrah terjadi. Kemerosotan moral, tingkah laku dan perbuatan-perbuatan orang dewasa yang tidak baik menjadi contoh atau tauladan bagi anakanak dan remaja berdampak timbulnya kenakalan remaja (Suamara , Humaedi, S., dan Santoso, MB., 2017)

Saat ini Indonesia mengalami krisis remaja yang memiliki karakter yang kuat, hal ini dibuktikan dengan melambannya pembangunan negara dan tingginya tingkat kenakalan remaja sebagai wujud dari kegagalan remaja dalam memanfaatkan potensi yang dimilikinya. Sementara di sisi lain, remaja sebagai kaum muda diharapkan dapat memegang kendali negara di masa depan, sehingga para pemuda (remaja) dapat menentukan arah pembangunan bangsa. Sehingga demi pembangunan bangsa Indonesia di masa depan, sebagai penerus bangsa maka pendidikan karakter bagi remaja merupakan hal yang sangat penting baik untuk menciptakan generasi yang berkualitas. Pada remaja yang memiliki karakter yang kuat cenderung dapat mencegah timbulnya kenakalan remaja.

Pendidikan karakter remaja dapat diintegrasikan dengan pendidikan formal, nonformal dan informal sebagai bentuk pencegahan timbulnya kenakalan remaja. Pendidikan karakter ini merupakan upaya untuk mengembangkan sikap etika, moral dan tanggung jawab yang dibutuhkan remaja dalam 


\begin{tabular}{|c|c|c|c|c|}
\hline $\begin{array}{c}\text { Prosiding Penelitian \& } \\
\begin{array}{c}\text { Pengabdian Kepada } \\
\text { Masyarakat }\end{array}\end{array}$ & $\begin{array}{c}\text { e ISSN : 2581-1126 } \\
\text { p ISSN : 2442-448X }\end{array}$ & Vol 5, No: 2 & Hal: $176-187$ & Juli 2018 \\
\hline
\end{tabular}

menjalani kehidupan sosialnya tanpa merugikan lingkungannya dengan tindakantindakan yang menyimpang dari nilai dan norma masyarakat.

Pendidikan karakter bagi para remaja dapat menyaring informasi-informasi yang tidak sesuai bagi mereka. Informasi 'tidak layak' tersebut dapat diperoleh dari lingkungan sekolah, keluarga, bahkan lingkungan pertemanan. Apalagi dengan arus informasi, yang diakselerasi dengan kemajuan teknologi informasi yang begitu pesat. Proses internalisasi melalui berbagai sumber informasi yang diperoleh remaja, dapat mempengaruhi pola pola pikir dan dapat mewujud dalam bentuk tingkah laku maupun perbuatan. Urgensi pendidikan karakter sebagai sebagai salah satu upaya untuk meningkatkan kualitas sumber daya manusia diperkuat dengan kebijakan pemerintah melalui UU No. 20 tahun 2003 tentang Pendidikan Karakter yang diperkuat oleh Peraturan Presiden No 87 tahun 2017 tentang Penguatan Pendidikan. Turunan kebijakan tersebut merupakan upaya perwujudan cita-cita pembangunan karakter sebagaimana diamanatkan dalam Pancasila dan Pembukaan UUD 1945 serta mengatasi permasalahan kebangsaan saat ini, maka pemerintah menjadikan pembangunan karakter sebagai salah satu program prioritas pembangunan nasional. Pendidikan karakter ditempatkan sebagai landasan untuk mewujudkan visi pembangunan nasional, yaitu "mewujudkan masyarakat berakhlak mulia, bermoral, beretika, berbudaya, dan beradab berdasarkan falsafah Pancasila" (Supinah dan Parmi, 2011: 1-2).

Remaja umumnya memiliki energi berlebih dan memiliki daya eksplorasi tinggi, sehingga seringkali aktifitasnya sulit dibatasi. Kondisi ini-lah yang membuat remaja rentan dan potensial melakukan tindak kenakalan remaja, apabila tidak diarahkan secara positif. Di Kota Bandung, belum lama ini sedang digiatkan gerakan 'Maghrib mengaji', yang kegiatan ini dapat menjadi wahana bagi para remaja untuk

\footnotetext{
${ }^{1}$ Nunung Unayah dan Muslim Sabarisman,

"Fenomena Kenakalan Remaja dan Kriminalitas" dalam
}

memperkuat karakter. Dalam kegiatan tersebut bukan sekedar membaca Al Qur'an, tetapi para remaja dapat juga menggali pengetahuan dan memperkuat nilai-nilai luhur, untuk selanjutnya dapat secara konsisten diterapkan dalam kehidupan keseharian. Dengan demikian, gerakan 'Maghrib mengaji' apabila diikuti dengan benar dan konsisten diterapkan, maka dapat menghindarkan mereka dari kenakalan. Kegiatan atau gerakan 'Maghrib mengaji' merupakan wahana pendidikan karakter yang tidak cukup hanya dilakukan di lingkungan masjid, tetapi juga diterapkan dalam lingkungan ayang lebih luas, seperti keluarga, pertemanan, ketetanggaan, komunitas dan lingkungan sosial lainnya.

Tulisan ini mencoba membahas pendidikan karakter remaja dikaitkan dengan pencegahan kenakalan remaja. Kegiatan pendidikan karakter dapat diinisiasi siapa saja, baik oleh pemerintah atau pun masyarakat. Inisiasi 'gerakan Maghrib mengaji' merupakan gerakan yang digagas oleh Pemerintah Kota Bandung, khususnya oleh Ridwan Kamil sebagai walikotanya. Berdasarkan hal tersebut, pendidikan karakter bagi remaja dan 'gerakan Maghrib mengaji' yang coba dibahas dalam tulisan ini.

\section{Pembahasan}

\section{Masa Remaja}

Masa remaja sering dikenal dengan istilah masa 'pemberontakan'. Pada masa-masa ini, seorang anak yang baru mengalami pubertas seringkali menampilkan beragam gejolak emosi, menarik diri dari keluarga, serta mengalami banyak masalah, baik di rumah, sekolah, atau di lingkungan rumah maupun di lingkungan pertemanannya. Kenakalan remaja pada saat ini, seperti yang banyak diberitakan di berbagai media, dapat dikatakan sudah melebihi batas yang sewajarnya. Banyak anak remaja dan anak di bawah umur rentang bersentuhan dengan permasalahan sosial, diantaranya mengenal rokok, narkoba, free sex,

Sosio Informa Vol. 1, No. 02, Mei - Agustus, Tahun 2015 


\begin{tabular}{|c|c|c|c|c|}
\hline $\begin{array}{c}\text { Prosiding Penelitian \& } \\
\text { Pengabdian Kepada } \\
\text { Masyarakat }\end{array}$ & $\begin{array}{c}\text { e ISSN : 2581-1126 } \\
\text { p ISSN : 2442-448X }\end{array}$ & Vol 5, No: 2 & Hal: $176-187$ & Juli 2018 \\
\hline
\end{tabular}

tawuran pencurian, dan terlibat banyak tindakan kriminal lainnya yang menyimpang dari norma-norma yang berlaku di masyarakat dan berurusan dengan hokum (Nunung Unayah , dan Muslim Sabarisman, 2015)

Hasil Survey Demografi Kesehatan Indonesia (SDKI 2007) yang dilansir dari ( http://ntb.bkkbn.go.id ) menunjukkan jumlah remaja di Indonesia mencapai $30 \%$ dari jumlah penduduk, jadi sekitar 1,2 juta jiwa. Namun kondisi remaja di Indonesia saat ini dapat digambarkan sebagai berikut:

1. Pernikahan usia remaja

2. Sex pra nikah dan Kehamilan tidak dinginkan

3. Aborsi 2,4 jt : 700-800 ribu adalah remaja

4. MMR 343/100.000 (17.000/th, 1417/bln, 47/hr perempuan meninggal) karena komplikasi kehamilan dan persalinan

5. HIV/AIDS: 1283 kasus, diperkirakan 52.000 terinfeksi (fenomena gunung es), $70 \%$ remaja

6. Miras dan Narkoba.

Hasil penelitian BNN bekerja sama dengan UI menunjukkan:

1. Jumlah penyalahguna narkoba sebesar $1,5 \%$ dari populasi atau 3,2 juta orang, terdiri dari $69 \%$ kelompok teratur pakai dan $31 \%$ kelompok pecandu dengan proporsi laki-laki sebesar $79 \%$, perempuan $21 \%$.

2. Kelompok teratur pakai terdiri dari penyalahguna ganja $71 \%$, shabu $50 \%$, ekstasi $42 \%$ dan obat penenang $22 \%$.

3. Kelompok pecandu terdiri dari penyalahguna ganja $75 \%$, heroin / putaw $62 \%$, shabu $57 \%$, ekstasi $34 \%$ dan obat penenang $25 \%$.

\footnotetext{
${ }^{2}$ Rijalihadi G , "FENOMENA KENAKALAN REMAJA DI INDONESIA" dalam http://ntb.bkkbn.go.id , 2 september 2011

${ }^{3}$ Lis Binti Muawanah dan Herlan Pratiko , “KEMATANGAN EMOSI, KONSEP DIRI DAN KENAKALAN
}

4. Penyalahguna Narkoba Dengan Suntikan (IDU) sebesar 56\% (572.000 orang) dengan kisaran 515.000 sampai 630.000 orang.

5. Beban ekonomi terbesar adalah untuk pembelian / konsumsi narkoba yaitu sebesar Rp. 11,3 triliun.

6. Angka kematian (Mortality) pecandu 15.00 orang meninggal dalam 1 tahun.

Pada dasarnya kenakalan remaja merupakan bentuk dari kekeliruan mereka dalam memproses informasi yang mereka dapatkan. Menurut Rijalihadi ${ }^{2}$ Kenakalan remaja biasanya dilakukan oleh remaja-remaja yang gagal dalam menjalani proses-proses perkembangan jiwanya, baik pada saat remaja maupun pada masa kanak-kanaknya. Masa kanak-kanak dan masa remaja berlangsung begitu singkat, dengan perkembangan fisik, psikis, dan emosi yang begitu cepat.

Menurut Lis dan Herlan (2012) kenakalan remaja adalah ${ }^{3}$ suatu perilaku remaja melanggar status, membahayakan diri sendiri, menimbulkan korban materi pada orang iain, dan perilaku menimbulkan korban fisik pada orang lain. Perilaku melanggar status merupakan perilaku dimana remaja suka melawan orang tua, membolos sekolah, pergi dari rumah tanpa pamit. Perilaku membahayakan diri sendiri, antara lain mengendarai kendaraan bermotor dengan kecepatan tinggi (bahkan tanpa helm), menggunakan narkotika, menggunakan senjata, keluyuran malam, dan pelacuran.

Kenakalan remaja meliputi semua perilaku yang menyimpang dari norma-norma hukum pidana yang dilakukan oleh remaja ${ }^{4}$. Perilaku tersebut dapat merugikan dirinya sendiri dan orang-orang di sekitarnya. Tentunya perilaku yang merugikan dan merusak diri dan orang lain, sudah tidak lagi sebagai sesuatu yang

REMAJA", dalam JURNAL PSIKOLOGI VOLUME 7, NO.1, APRIL 2012: 490 - 500

${ }^{4}$ Dadan Sumara, Sahadi Humaedi, Meilanny Budiarti Santoso "Kenakalan Remaja dan Penanganannya" dalam ,Jurnal Penelitian \& PPM , ISSN: 2442-448X, Vol 4, No: 2 Hal: 129 - 389, Juli 2017 


\begin{tabular}{|c|c|c|c|c|}
\hline $\begin{array}{c}\text { Prosiding Penelitian \& } \\
\text { Pengabdian Kepada } \\
\text { Masyarakat }\end{array}$ & $\begin{array}{c}\text { e ISSN : 2581-1126 } \\
\text { p ISSN : 2442-448X }\end{array}$ & Vol 5, No: 2 & Hal: $176-187$ & Juli 2018 \\
\hline
\end{tabular}

dianggap wajar oleh lingkungan. Suatu perbuatan yang dibiarkan (permisif) terus berulang, maka dapat mengarah menjadi kebiasaan, bahkan lebih jauh dapat terstruktur secara budaya. Oleh karena itu, upaya pencegahan perlu dilakukan, berupa peringatan atau larangan sesuai nilai dan norma yang berlaku. Setiap elemen dalam setiap lingkungan sosial perlu menjadi bagian yang utuh dan simultan dalam membantu dan membimbing (advokasi) remaja mencapai potensi positif terbaik yang mereka miliki.

\section{Perkembangan Kognitif Remaja}

Masa remaja menurut Garison dan Garison (Hasselt \& Hersen 1987) adalah masa 'in between periode', yaitu masa dimana individu tidak bisa digolongkan lagi sebagai anak-anak, namun belum matang jika digolongkan menjadi orang dewasa. Menurut Ramsey (1987), rentang usia remaja dimulai pada usia 10-13 tahun dan berakhir pada usia 19-21 tahun (Hasselt \& Hersen, 1987). Turner dan Helms (1991) mengelompokkan usia remaja antara 1319 tahun. World Health Organization (WHO) membagi usia remaja menjadi dua yaitu remaja awal (10-14 tahun) dan remaja akhir (15-20 tahun). Sementara itu menurut Sarwono, di Indonesia usia remaja adalah dari umur 14 sampai 24 tahun.

Seperti yang kita ketahui bahwa remaja merupakan masa yang masih bersemanngat tinggi dimana perkembangan yang ada pada dirinya sedang bekerja secara optimal. Menurut Desmita masa remaja adalah suatu periode kehidupan di mana kapasitas untuk memperoleh dan menggunakan pengetahuan secara efisien mencapai puncaknya. Hal ini dikarenakan selama periode ini, proses pertumbuhan otak pada remaja mencapai kesempurnaan. Sistem saraf yang berfungsi memperoses informasi berkembang dengan cepat. Di samping itu, pada masa remaja ini

\footnotetext{
${ }^{5}$ Seprianing Aroma dan Dwi Retno Suminar,

"Hubungan Antara Tingkat Kontrol Diri Dengan

Kecenderungan Perilaku Kenakalan Remaja “, dalam
}

juga terjadi reorganisasi lingkaran saraf prontal lobe - belahan otak bagian depan sampai pada belahan atau celah sentral. Prontal lobe ini berfungsi dalam aktivitas kognitif tingkat tinggi, seperti kemampuan merumuskan perencanaan strategis atau kemampuan mengambil keputusan. Perkembangan prontal lobe tersebut sangat berpengaruh terhadap kemampuan kognitif remaja, sehingga mereka mengembangkan kemampuan penalaran yang memberinya suatu tingkat pertimbangan moral dan kesadaran sosial yang baru.

Aktivitas kognitif pada remaja ini biasanya di gunakan untuk mengeksplorasi pengetahuan yang dia dapatkan di lingkungan sosialnya berupa pengetahuan yang memiliki relevansi terhadap pembentukan identitas remaja atau disebut juga dengan pencarian jati diri, Iidentitas tersebut membantu ia menjalankan perannya di masyarakat. Sebagaimana yang di katakana oleh Seprianing ${ }^{5}$ bahwa remaja memiliki sifat selalu berusaha mencari dan menemukan hal-hal baru yang belum dikenal, sehingga harus melakukan penggalian informasi yang sebanyak-banyaknya. Hal tersebut tentu mempunyai relevansi dengan proses eksplorasi dalam rangka pembentukan identitas diri. Sedangkan kekuatan kemauan remaja untuk melaksanakan berbagai alternatif yang dipilih, juga mempunyai relevansi dengan komitmen dalam proses pembentukan identitas diri.

Eksplorasi merupakan suatu aktifitas yang dilakukan untuk menggali dan mencari informasi atau alternatif sebanyak-banyaknya dan mempunyai hubungan dengan kepentingan di masa depan. Berbagai informasi dan alternatif tersebut selanjutnya dibandingkan di antara satu dengan yang lain, selanjutnya dapat dipilih alternatif yang dipandang paling memberikan keuntungan dan jaminan masa depan yang lebih baik. Pencarian informasi tersebut dapat dilakukan dengan membaca berbagai sumber (buku, koran, majalah, media

Jurnal Psikologi Pendidikan dan Perkembangan Vol. 01 No. 02, Juni 2012. 


\begin{tabular}{|c|c|c|c|c|}
\hline $\begin{array}{c}\text { Prosiding Penelitian \& } \\
\text { Pengabdian Kepada } \\
\text { Masyarakat }\end{array}$ & $\begin{array}{c}\text { e ISSN : 2581-1126 } \\
\text { p ISSN : 2442-448X }\end{array}$ & Vol 5, No: 2 & Hal: $176-187$ & Juli 2018 \\
\hline
\end{tabular}

masa yang lain), melakukan pengamatan terhadap aktivitas kehidupan yang berhubungan dengannya; seperti orang tua, guru, orang yang dianggap penting, dan sebagainya. Aktifitas eksplorasi dapat pula dilakukan dengan menanyakan kepada orang yang telah aktif secara langsung dalam suatu jenis dominan kehidupan tertentu. ${ }^{6}$

\section{Peran Lingkungan terhadap Perkembangan Remaja}

Kartika dalam Fani dan Lathifah ${ }^{7}$ menyatakan bahwa, remaja membutuhkan dukungan dari lingkungan. Dukungan sosial yang diterima remaja dari lingkungan, baik berupa dorongan semangat, perhatian, penghargaan, bantuan dan kasih sayang membuat remaja menganggap bahwa dirinya dicintai, diperhatikan, dan dihargai oleh orang lain. Jika individu diterima dan dihargai secara positif, maka individu tersebut cenderung mengembangkan sikap positif terhadap dirinya sendiri dan lebih menerima dan menghargai dirinya sendiri. Sehingga remaja mampu hidup mandiri ditengah-tengah masyarakat luas secara harmonis (Fani Kumalasari dan lathifah Nur Ahyani, 2012)

Dalam proses penyesuaian diri dengan lingkungan seseorang perlu menyeimbangkan interaksi dengan dirinya dan lingkungan sosialnya. Pada dasarnya interaksi merupakan proses saling mempengaruhi dan di pengaruhi, proses timbal balik dalam interaksi mambuat lingkungan dan diri saling menyesuaikan. Dengan demikian kehidupan sosial remaja sangat bergantung dari keadaan lingkungannya. Apabila keadaan lingkungannya baik dan mendukung remaja untuk tumbuh kembang dengan baik maka remaja juga bisa tumbuh dewasa dan menjadi orang yang baik. Begitu juga sebaliknya apabila remaja tinggal di lingkungan kurang baik maka remaja juga dapat tumbuh menjadi orang seperti yang kebanyakan

\footnotetext{
6 Purwadi , "Proses Pembentukan Identitas Remaja" , dalam Humanitas : Indonesian Psychologycal Journal Vol.1 No.1, Januari 2004:43-52.
}

ada lingkungannya walaupun itu tidak baik. (Novita, 2016) .

Lingkungan yang menolak penyimpangan dapat membentuk masyarakat yang menolak penyimpangan juga, sementara lingkungan yang membiarkan terjadinya penyimpangan atau kenakalan remaja oleh remaja kenakalan remaja tersebut dapat dianggap suatu hal yang wajar dan tidak salah. Pembenaran terhadap kenakalan remaja itu lah yang membentuk budaya menyimpang di masyarakat, sehingga lingkungan tersebut berperan penting dalam membentuk masyarakat dan masyarakat merupakan wujud dan interpretasi dari kondisi lingkungannya.

\section{Peran Teman Sebaya}

Masa remaja merupakan masa dimana teman sebaya menjadi aspek yang sangat penting dalam proses peralihannya dari kanak kanak menuju dewasa, pendampingan teman sebaya pada tahap ini menggantikan peran pendampingan orang tua maupun guru, karena teman sebayanya dinilai lebih mengerti kondisi psikososialnya dibanding guru dan orang tua sehingga remaja lebih mendengar dan mengikuti apa yang menjadi pandangan dari teman sebayanya.

Erikson (1950, 1968 dalam Santrock 1995) melihat masa remaja sebagai tahapan pencarian identitas diri dan merupakan masa transisi dari masa kanak-kanak menuju masa dewasa. Di sisi lain, secara fisiologis remaja mengalami pertumbuhan fisik dan hormonal yang pesat, yang selanjutnya berpengaruh pula kepada ketidakstabilan emosi remaja. Selain itu, masa remaja merupakan masa dimana pengaruh teman sebaya sangat kuat, baik pengaruh negatif maupun positif.

Secara umum, Hartup dan Stevens (1999) dalam Baron dan Byrne (2005) mengatakan bahwa memiliki teman adalah suatu hal yang

\footnotetext{
${ }^{7}$ Fani Kumalasari dan lathifah Nur Ahyani , "Hubungan Antara Dukungan Sosial Dengan Penyesuaian Diri Remaja Di Panti Asuhan “, dalam Jurnal Psikologi Pitutur, Volume 1No.1, Juni 2012.
} 


\begin{tabular}{|c|c|c|c|c|}
\hline $\begin{array}{c}\text { Prosiding Penelitian \& } \\
\begin{array}{c}\text { Pengabdian Kepada } \\
\text { Masyarakat }\end{array}\end{array}$ & $\begin{array}{c}\text { e ISSN : 2581-1126 } \\
\text { p ISSN : 2442-448X }\end{array}$ & Vol 5, No: 2 & Hal: $176-187$ & Juli 2018 \\
\hline
\end{tabular}

positif sebab teman dapat mendorong selfesteem dan menolong dalam mengatasi stress, tetapi teman juga dapat memiliki efek negatif jika mereka antisosial, menarik diri, tidak suportif, argumentatif, atau tidak stabil. Peer group merupakan suatu wadah untuk bersosialisasi.

Menurut Havighurst dalam Ahmadi (2004) peer group memiliki tiga fungsi, yaitu:
a. Mengajarkan kebudayaan
b. Mengajarkan mobilitas sosial atau perubahan status.
c. Memberi peranan sosial yang baru.

Di dalam peer group atau pertemanan teman sebaya remaja dapat belajar banyak hal diantaranya adalah budaya, status dan peranannya baik dalam kehidupan keluarga, sekolah maupun masyarakat, hal tersebut tentunya sangat berguna bagi remaja dalam proses pencarian jati dirinya.

\section{Urgensi Pendidikan Karakter pada Remaja}

Menurut Badan Pusat Statistik (BPS) dari 233 juta jiwa penduduk Indonesia, 26,8\% atau 63 juta jiwa adalah remaja berusia 10 sampai 24 tahun. Dari data tersebut, Indonesia diprediksi akan mendapat Bonus Demografi, dimana penduduk dengan umur produktif sangat besar sementara usia muda semakin kecil dan usia lanjut belum banyak, di tahun 2020 - 2030 . Jumlah usia angkatan kerja (15 - 64 tahun) pada 2020 - 2030 akan mencapai 70 persen, sedangkan sisanya, 30 persen, adalah penduduk yang tidak produktif (di bawah 15 tahun dan diatas 65 tahun). Jika pembinan terhadap remaja atau penduduk umur produktif tidak segera dilakukan, dapat dipastikan Indonesia tidak bisa melahirkan sumber daya manusia yang baik dan berkualitas. (Effendi, 2018)

\footnotetext{
${ }^{8}$ Muhammad Kristiawan, "Telaah Revolusi Mental dan Pendidikan Karakter Dalam Pembentukan Sumber Daya Manusia Indonesia yang Pandai dan Berakhlak Mulia “, dalam ta'dib ,Volume 18 No.1, juni 2015
}

Pendidikan karakter merupakan pembinaan yang baik bagi remaja sebagai generasi yang diandalkan dalam pembangunan negara. Masa remaja merupakan masa yang sangat rentan karena cenderung lebih menyukai dan ingin mencoba hal-hal baru baru dari apa yang mereka lihat atau mereka dengar tanpa mempertimbangkan baik atau buruknya dampak yang akan mereka rasakan dalam jangka pendek maupun jangka panjang yang menyangkut masa depannya. Sehingga remaja yang dapat menggantikan generasi senior di masa yang akan datang tentunya sangat membutuhkan pembinaan berupa pendidikan karakter yang mampu mengarahkan mereka menjadi sosok yang di harapkan oleh bangsa. Sebagaimana yang dikatakan oleh Muhammad Kristiawan pendidikan karakter pada remaja dilakukan untuk pengendalian diri supaya remaja tidak terjerumus ke dalam karakter negatif. Supaya karakter positif dapat diinternalisasi menjadi karakter yang permanen $^{8}$

Azra memberikan pengertian bahwa pendidikan merupakan suatu proses di mana suatu bangsa mempersiapkan generasi mudanya untuk menjalankan kehidupan dan untuk memenuhi tujuan hidup secara efektif ${ }^{9}$. Pada dasarnya pendidikan bukan hanya sekedar pengajaran melainkan merupakan suatu upaya peningkatan kemampuan sumber daya manusia agar dapat menjadi manusia yang mandiri serta dapat berkonstribusi terhadap masyarakat dan bangsanya. Proses pendidikan yang profesional dapat membentuk karakter pada peserta didiknya. Oleh karena itu dalam pelaksanaannya pendidikan karakter ini ber integrasi dengan pendidikan formal, informal, dan non formal agar dapat membentuk karakter positif khususnya di kalangan remaja. Sebab remaja masih berada dalam tahap pertumbuhan dan perkembangan yang memiliki kepribadian labil dan sedang mencari jati diri untuk membentuk karakter permanen. Pendidikan

\footnotetext{
${ }^{9}$ Azyumardi Azra. Paradigma Baru Pendidikan Nasional: Rekonstruksi dan Demokratisasi. Jakarta: Kompas, 2002, h.4.
} 


\begin{tabular}{|c|c|c|c|c|}
\hline $\begin{array}{c}\text { Prosiding Penelitian \& } \\
\text { Pengabdian Kepada } \\
\text { Masyarakat }\end{array}$ & $\begin{array}{c}\text { e ISSN : 2581-1126 } \\
\text { p ISSN : 2442-448X }\end{array}$ & Vol 5, No: 2 & Hal: $176-187$ & Juli 2018 \\
\hline
\end{tabular}

pada usia remaja menjadi momen yang penting dalam menentukan karakter seseorang setelah dewasa (Kristiawan, 2015).

Sebagaimana yang telah dipaparkan sebelumnya bahwa lingkungan formal (sekolah), informal (keluarga) dan non formal (pendidikan di luar sekolah) mempunyai peluang yang sama kuatnya dalam pengembangan karakter remaja. Sehingga dalam uapaya peningkatan kualitas sumber daya remaja perlu bekerja sama dan membangun komunikasi yang baik antara sekolah, keluarga, dan pendidikan nonformal dalam mengembangkan karakter anak remaja.

Untuk mendukung perwujudan cita-cita pembangunan karakter sebagaimana diamanatkan dalam Pancasila dan Pembukaan UUD 1945 serta mengatasi permasalahan kebangsaan saat ini, maka pemerintah menjadikan pembangunan karakter sebagai salah satu program prioritas pembangunan nasional. Pendidikan karakter ditempatkan sebagai landasan untuk mewujudkan visi pembangunan nasional, yaitu "mewujudkan masyarakat berakhlak mulia, bermoral, beretika, berbudaya, dan beradab berdasarkan falsafah Pancasila" (Supinah dan Parmi, 2011: 1-2).

Konstitusi bangsa Indonesia UUD Pasal 31 tentang Pendidikan dan Kebudayaan pada ayat 3 secara tegas menyebutkan bahwa pemerintah mengusahakan dan menyelenggarakan satu sistem pendidikan nasional yang meningkatkan keimanan dan ketaqwaan serta akhlak mulia dalam rangka mencerdaskan kehidupan bangsa. Kemudian dijabarkan dalam Undang-Undang Nomor 20, Tahun 2003 tentang Sistem Pendidikan Nasional disebutkan bahwa pendidikan adalah usaha sadar dan terencana untuk mewujudkan suasana belajar dan proses pembelajaran agar peserta didik secara aktif mengembangkan potensi dirinya untuk memiliki kekuatan spiritual keagamaan, pengendalian diri, kepribadian, kecerdasan, akhlak mulia, serta keterampilan yang diperlukan dirinya, masyarakat, bangsa dan negara (Mulia, 2010, p. 230) .
Sementara itu, Indonesia Heritage Foundation merumuskan beberapa bentuk karakter yang harus ada dalam setiap individu bangsa Indonesia di antaranya; cinta kepada Allah dan alam semesta beserta isinya, tanggung jawab, disiplin dan mandiri, jujur, hormat dan santun, kasih sayang, peduli, dan kerja sama, percaya diri, kreatif, kerja keras dan pantang menyerah, keadilan dan kepemimpinan, baik dan rendah hati, dan toleransi, cinta damai dan persatuan. Sementara itu, character counts di Amerika mengidentifikasikan bahwa karakter-karakter yang menjadi pilar adalah; dapat dipercaya (trustzoorthiness), rasa hormat dan perhatian (respect), tanggung jawab (responsibility), jujur (fairness), peduli (caring), kewarganegaraan (citizenship), ketulusan (honesty), berani (courage), tekun (diligence) dan integritas (integrity) (Hasanah, 2009)

\section{Implementasi Pendidikan Karakter pada Gerakan Maghrib Mengaji (pendidikan non formal)}

\section{Dilansir dari (https://www.republika.co.id )} 'Gerakan Maghrib Mengaji' merupakan program yang digagas Ridwan Kamil selaku Wali Kota Bandung untuk membudayakan kembali tradisi membaca Alquran setelah shalat Maghrib di kalangan masyarakat. Tujuan yang ingin dicapai dari Gerakan Magrib Mengaji ini di antaranya;

1. Menghidupkan kembali tradisi membaca Alquran setiap selesai shalat Magrib di seluruh masjid yang ada di wilayah Kota Bandung, yang mengharapkan masyarakat dapat memanfaatkan waktu antara Maghrib dan Isya dengan efektif untuk beribadah kepada Allah, memperdalam wawasan keagamaannya dan tidak menghabiskan waktunya untuk hal-hal yang kurang bermanfaat.

2. Sebagai upaya menumbuhkan kesadaran di tengah-tengah masyarakat akan fungsi dan peranan Al Qur`an bagi kehidupan manusia sehingga Alquran tetap dibaca dan dipelajari sekalipun telah tamat (khatam) dari Taman Pendidikan Alquran. 


\begin{tabular}{|c|c|c|c|c|}
\hline $\begin{array}{c}\text { Prosiding Penelitian \& } \\
\text { Pengabdian Kepada } \\
\text { Masyarakat }\end{array}$ & $\begin{array}{c}\text { e ISSN : 2581-1126 } \\
\text { p ISSN : 2442-448X }\end{array}$ & Vol 5, No: 2 & Hal: $176-187$ & Juli 2018 \\
\hline
\end{tabular}

3. Meningkatkan minat dan kemampuan masyarakat dalam membaca Alquran.

4. Meminimalisasi pengaruh negatif dari media teknologi informasi dan media elektronik.

5. Upaya memakmurkan masjid dengan kegiatan ibadah ,

6. Meningkatkan kerjasama antara orang tua, masyarakat dengan unsur pendidikan dan pemerintah, melalui pembinaan karakter anak-anak dengan program mengaji Alquran.

Sasaran utama dalam Program Maghrib Mengaji ini adalah seluruh komponen masyarakat khususnya remaja. Diharapkan program Magrib Mengaji ini bukan sekadar mengajarkan baca Alquran saja, tapi juga sebagai pendidikan karakter bagi mereka. Hingga saat ini, Gerakan Magrib Mengaji di Kota Bandung, terus berjalan di masjid-masjid di 251 kelurahan di Kota Bandung, dengan melibatkan sebanyak kurang lebih 2500 guru ngaji yang tersebar di 4000an masjid yang ada di Kota Bandung. (Basrah, 2018)

Dalam pelaksanannya agar tercapai pembentukan karakter yang efektif dan efisien jajaran pengajar perlu memanfaatkan dan mengoptimalkan kondisi remaja dalam proses pembelajarannya dengan menggunakan metode yang cocok bagi peserta didiknya (remaja) tanpa menghilangkan tujuan dari diadakannya magrib mengaji

a. Metode transfer ilmu yang digunakan dalam proses tadarus, remaja secara bersama-sama membaca Al-qur'an baik arab maupun artinya, setelah itu mereka ditugaskan untuk memilih ayat yang paling bermakna bagi dirinya dan paling terbayang bagaimana implementasi atau pengaplikasian ayat tersebut agar dapat diaplikasikan di kehidupan harinya. Karena pada dasarnya ayat-ayat al-quran merupakan pedoman bagi setiap umat Islam untuk menjalani aktivitas hidupnya secara benar sehingga nanti mendapat balasan surga .
Selanjutnya masing-masing dari mereka memaparkan makna dari ayat yang mereka pilih, alasan mereka memilih Ayat tersebut, dan menjelaskan bagaimana ayat tersbut di aplikasikan di kehidupan sehari-hari. Dan yang terakhir mereka dipersilahkan untuk saling bertukar pengetahuan dengan mengungkapkan hasil eksplorasinya mengenai ayat yang dibahasnya. Sehingga masing-masing dari mereka mendapatkan pelajaran dari hasil eksplorasinya dan mendapatkan pengajaran dari hasil eksplorasi teman sebayanya.

b. Metode cerita teladan yang di sampaikan oleh jajaran pendidik, dalam pelaksanaanya guru tidak hanya mengungkapkan bagaimana sikap teladan seorang rasul, atau bagaimana kehidupan di jaman dahulu, tetapi juga mengintegrasikan kehidupan dulu dengan kehidupan sekarang agar cerita tersebut bisa di teladani dengan baik oleh para peserta didiknya. Sebagai contoh, berikut merupakan contoh narasi cerita yang mengintegrasikan kehidupan dulu dengan kehidupan jaman sekarang dengan bahasa yang ringan dan mudah di cerna oleh usia remaja dan melibatkan daya eksplorasi dan imajinasi mereka.

Pernah dikisahkan kalau dulu pernah ada peperangan yang dimenangkan oleh umat Islam dan ada kubu musuh yang ditawan oleh orang Islam, mereka memperhatikan bagaimana gerak gerik orang Islam untuk mencari tahu strategi kemenangannya. Dimalam hari mereka melihat orang Islam berkumpul serta menangis saat membaca Al-Qur'an, tapi kan kalau hanya membaca mah ga akan nangis ya? karena mereka aja saat berperang meninggalkan keluarganya dengan hati yang sangat lapang. Kecuali mereka menaruh hati pada itu dan cintanya bahkan melebihi cinta pada keluarganya apalagi harta yang dimilikinya, tentu mereka tidak hanya membacanya melainkan mengkajinya dan merasakan qur'an ada dalam hatinya yang bergetar dan luluh 


\begin{tabular}{|c|c|c|c|c|}
\hline $\begin{array}{c}\text { Prosiding Penelitian \& } \\
\text { Pengabdian Kepada } \\
\text { Masyarakat }\end{array}$ & $\begin{array}{c}\text { e ISSN : 2581-1126 } \\
\text { p ISSN : 2442-448X }\end{array}$ & Vol 5, No: 2 & Hal: $176-187$ & Juli 2018 \\
\hline
\end{tabular}

ketika dibahas tentang sesuatu yang amat dicintainya.

Nah terus melihat keadaan seperti itu si musuh menulis surat kepada temannya bilang kalau "orang Islam ga akan kalah dalam perang, kalau mau ngalahin mereka perlu dengan cara menjauhkan Qur'an dari mereka" karena kan orang Islam mah ga takut mati soalnya udah yakin yg menghidupkan dan mematikan bukan manusia, sedangkan mereka (lawannya yang kalah) takut mati,takut hartanya tidak bisa lagi mereka nikmatin, takut kekuasaannya di rebut oleh musuh dan banyak ketakutan lainnya deh pokonya. Lagian kan emang salah satu alasan Abu Jahal gamau jadi pengikut Rasulullah Muhammad gara gara takut kekuasaannya di ambil alih meskipun mereka percaya Allah yg nyiptain mereka,tapi karna udah cinta terhadap duniawi dia rela kafir asalkan kekuasaan dan kekayaanya dapat bertahan dalam kubunya. Mungkin contoh yang lebih dekat lagi semisal pacaran rela ngasih segalanya demi mengabdi atau menuruti apa yang dinginkan sang pasangan, mulai dari memberikan tangan untuk sekedar di genggam, memberikan badan untuk "sekedar" dipeluk, memberikan bibir untuk "sekedar" dicium dan terus hingga lebih dari itu,dan mungkin itu adalah satusatunya alasan pacaran dilarang karena itu merupakan penjabaran dari QS. 17: 32 yang berisi tentang larangan mendekati zina yang membuat Allah tidak lagi menjadi Zat yang paling di cintai oleh hamba-Nya.

Lalu bagaimana dengan kalian apakah Qur'an yang dibaca sempat dikaji? atau membacapun kalo inget ? Nah berarti kalau dalam peperangan orang-orang yang jauh dari Al-Qur'an adalah orang yang kalah dalam berperang, dan apabila meninggal dalam keadaan jauh mungkinkah mendapatkan syurganya Allah ?

c. Metode re-call pengetahuan yang dimana setelah proses pembelajarn berlangsung jajaran pengajar mengukur pemahaman peserta didiknya melalui pertanyaanpertanyaan sederhana seputar apa yang telah dijelaskan sebelumnya dan di pertemuan selanjutnya diingatkan kembali proses pembelajaran di hari sebelumnya sehingga nilai dan norma dapat tertanam dengan baik .Nilai dan norma ini mampu menjadi pola pikir bagi mereka dalam menjalankan aktivitasnya sehingga mereka bisa menjauhi kenakalan kenakalan remaja ataupun bentuk-bentuk penyimpangan lainnya dan dengan sendirinya kenakalan remaja akan berkurang.

\section{Kesimpulan dan saran}

Kinerja optimal dalam otak remaja perlu di manfaatkan untuk menggali nilai nilai positif yang terkandung di lingkungan pendidikan formal, nonformal, maupun informal. Sebab masa remaja adalah masa penentu, dimana pada tahap ini aktivitas eksplorasi remaja menentukan bagaimana dirinya di masa yang akan datang. Penggalian nilai-nilai positif di masa remaja akan membentuk karakter positif yang menjadi bekal masa dewasa nanti agar mampumemposisikan dirinya dengan lingkungan dan negaranya, serta menjalankan peran sebagai warga masyarakat, warga negara, bahkan pemangku jabatan pemerintahan yang baik.

Remaja sebagai asset yang di andalkan dalam pembangunan negara tidak seharusnya mengotori lingkungan negara dengan melakukan kenakalan remaja, melainkan membantu pemerintah memperbaiki lingkungan, agar dapat menciptakan negara yang aman, nyaman dan sejahtera.

Pada dasarnya setiap remaja berpotensi melakukan bentuk-bentuk kenakalan remaja, namun dengan adanya pendidikan karakter yang terintegrasi dengan pendidikan formal, informal, maupun nonformal, remaja dapat menjaga dan memegang tinggi nilai dan norma yang ada di masyarakat. Maghrib mengaji merupakan pendidikan nonformal yang bertujuan untuk membentuk karakter qur'ani di kalangan masyarakat agar masyarakat terutama 


\begin{tabular}{|c|c|c|c|c|}
\hline $\begin{array}{c}\text { Prosiding Penelitian \& } \\
\text { Pengabdian Kepada } \\
\text { Masyarakat }\end{array}$ & $\begin{array}{c}\text { e ISSN : 2581-1126 } \\
\text { p ISSN : 2442-448X }\end{array}$ & Vol 5, No: 2 & Hal: $176-187$ & Juli 2018 \\
\hline
\end{tabular}

remaja di kalangan umat muslim dapat mengembangkan karakter positif yang mampu membuat mereka menghindari tindakantindakan kejahatan berupa kenakalan remaja yang mengotori nilai dan norma yang telah ada, bahkan mengotori Pancasila sebagai ideologi masyarakat Indonesia.

Sangat di sayangkan program Maghrib mengaji ini belum di aplikasikan di seluruh wilayah Indonesia, dan seharusnya setiap agama juga membuat program yang mampu membentuk dan mengembangkan karakter penganutnya sesuai dengan pengajaran-pengajaran yang ada di dalam agamanya. Karena pada dasarnya setiap agama mengajarkan kebaikan bagi para penganutnya agar para penganutnya dapat menjalankan aktivitas hidupnya dengan baik.

Pendidikan nonformal ini di harapkan dapat di rasakan oleh seluruh masyarakat Indonesia dengan latar belakang agama apapun berupa bentuk pengajaran agama yang menanamkan nilai-nilai kebaikan. Karena apabila nilai-nilai kebaikan sudah tertanam pada seseorang, maka segala bentuk perbuatan maupun ucapan yang ia keluarkan merupakan kebaikan pula , dengan demikian masyarakat Indonesia manjadi masyarakat yang harmoni aman, nyaman dan sejahtera tanpa adanya gangguan-gangguan penyimpangan.

\section{Daftar Pustaka}

Basrah, R. S. (2018, Februari 7). Gerakan Maghrib Mengaji , Upaya Membangun Generasi Qur'ani. Retrieved juni 10, 2018, from Berita Nasional Republika: https://www.republika.co.id

Dadan suamara, Sahadi Humaedi dan Meilanny Budiarti. (2017, juli). Kenakalan Remaja dan Penanganannya. Jurnal Penelitian \& PPM, 129-389.

Effendi, Z. (2018, februari 15). Begini Cara Risma Cegah Kenakalan Remaja di Sekolah. Retrieved 15 juni, 2018, from detikNews: https://news.detik.com/berita-jawa-timur
Fajarini, U. (2014, desember). Peranan Kearifan LOkal dalam Pendidikan Karakter. Sosio Didaktika: Vol. 1, No. 2, 124-130.

Fani Kumalasari dan lathifah Nur Ahyani. (2012, juni). Hubungan Antara Dukungan Sosial Dengan Penyesuaian Diri Remaja Di Panti Asuhan. Jurnal Psikologi Pitutur, Volume 1No.1.

Hasanah, A. (2009). Pendidikan Berbasis Karakter. Retrieved from Bataviase detail berita: http://bataviase.co.id

Iga Serpianing Aroma, Dewi Retno Suminar. (2012, juni). Hubungan Antara Tingkat Kontrol Diri Dengan Kecenderungan Perilaku Kenakalan Remaja. Jurnal Psikologi Pendidikan dan Perkembangan Vol.01 No.02.

Kristiawan, M. (2015, juni). Telaah Revolusi Mental dan Pendidikan Karakter Dalam Pembentukan Sumber Daya Manusia Indonesia yang Pandai dan Berakhlak Mulia. Ta'dib ,Volume 18 No.1.

Mahmuda. (2017). Konsep Negara Ideal / Utama (AL-Madinah AL-Fadhilah) Menurut AL - Farabi. Al-Lubb , vol.2 no.2, 286-300.

Mulia, P. K. (2010, mei). Sabar Budi Raharjo. Jurnal Pendidikan dan Kebudayaan, Vol. 16, Nomor 3.

Nindya P. N. , Margaretha R. (2012).

Hubungan antara Kekerasan Emosional pada Anak terhadap Kecenderungan Kenakalan Remaja. Jurnal Psikologi Klinis dan Kesehatan Mental Vol.1.No.02.

Novita, I. F. (2016, september 4). Peran Pekerja Sosial dalam Pembinaan Remaja di Balai Perlindungan dan Rehabilitasi Sosial Remaja Daerah Istimewa Yogyakarta. Yogyakarta, Indonesia, Jawa.

Nunung Unayah, dan Muslim Sabarisman. (2015, june 9). fenomena kenakalan remaja dan kriminalitas. Sosio Informa Vol.1.

Raharjo, ST. 2015. Dasar Pengetahuan Pekerjaan Sosial. Bandung: Unpad Press 2015. Keterampilan Pekerjaan

Sosial, Dasar-dasar. Bandung: Unpad Press. 
2015. Pekerjaan Sosial Generalis,

Bekerja Bersama Organisasi dan Komunitas.

Bandung: Unpad Press.

Rehasti Dya Rahayu dan Winati Wign. (2011). Pengaruh Lingkungan Keluarga, Sekolah dan Masyarakat terhadap Persepsi Gender Mahasiswa Laki-laki dan Perempuan. Jurnal Transdisiplin Sosiologi, Komunikasi, dan Ekologi Manusia, 247-260.
Renata, Muhammad Kristiawan, Fatmi Andi Rizki Pratami. (2017, November 25).

Perbincaraan Pendidikan Karakter. Prosiding Seminar Nasional 20 Program Pascasarjana Universitas PGRI Palembang, 327-333.

Wibowo, E. (2008). Perencanaan Strategi Pembangunan di Indonesia. jurnal ekonomi dan kewirausahaan, 16-24. 